\title{
Identification of Resistance Genes Effective Against Rice Bacterial Blight Pathogen in Eastern India
}

\author{
Marella Lalitha Shanti, Central Rice Research Institute (CRRI), Cuttack 753 006, India; M. L. C. George, C. M. \\ Vera Cruz, M. A. Bernardo, R. J. Nelson, and H. Leung, International Rice Research Institute (IRRI), Los \\ Banos, Philippines; and J. N. Reddy and R. Sridhar, CRRI, India
}

\begin{abstract}
Shanti, M. L., George, M. L. C., Vera Cruz, C. M., Bernardo, M. A., Nelson, R. J., Leung, H., Reddy, J. N., and Sridhar, R. 2001. Identification of resistance genes effective against rice bacterial blight pathogen in eastern India. Plant Dis. 85:506-512.

Breeding for bacterial blight resistance in rice requires an understanding of the contemporary pathogen populations in the locations where resistance genes are to be deployed. We characterized 450 strains of Xanthomonas oryzae pv. oryzae collected from three states of India using polymerase chain reaction fingerprinting and virulence analysis. This pathogen collection was differentiated into 17 haplotypes (12 lineages at $80 \%$ similarity level). Significant differences in the distribution of haplotypes were observed among regions. Virulence analysis of the pathogen collection revealed nine pathotypes. Among the populations from three regions, the Orissa population was the most diverse, consisting of 11 out of 17 haplotypes and five out of nine pathotypes detected in the total collection. Representative pathotypes were used to evaluate seven near-isogenic lines carrying individual bacterial blight resistance genes (Xa3, Xa4, xa5, $\mathrm{Xa}$, Xa10, $\mathrm{xa}$ 13, and $\mathrm{Xa21}$ ) and gene pyramids. Pathogen strains compatible to individual genes were present in detectable frequencies, although no single strain could overcome all resistance genes. Gene combinations Xa4 + xa5, $x a 5+\mathrm{X} a 21$, and Xa4 $+x a 5+X a 21$ conferred a broad spectrum of resistance to all the strains evaluated, supporting the strategy of pyramiding appropriate resistance genes.
\end{abstract}

Additional keywords: AMOVA, disease resistance, DNA fingerprinting

Bacterial blight of rice caused by Xanthomonas oryzae pv. oryzae is a major constraint for rice production in rainfed and irrigated environments. The pathogen is known to exhibit pathogenic variation, with diverse pathotypes or races in different rice-growing areas. Although over 20 resistance genes have been genetically defined in rice cultivars and germ plasm $(12,17)$, the effectiveness of resistance genes varies over locations due to geographical structuring of the pathogen population. Knowledge of the pathogen population structure and virulence characteristics is therefore essential for a successful breeding program (14).

Corresponding author: C. M. Vera Cruz

E-mail: cveracruz@cgiar.org

This study was a collaborative project between IRRI and CRRI (ICAR) supported in part by a grant from Asian Development Bank (RETA 5510 and 5667) for the Asian Rice Biotechnology Network.

Current address of R. J. Nelson: Centro Internacional de la Papa (CIP), Apartado 1558, Lima 12, Peru; current address of M. C. L. George: CIMMYT, c/o IRRI, Los Baños, Philippines.

Accepted for publication 22 January 2001.

Publication no. D-2001-0313-01R

(c) 2001 The American Phytopathological Society
Various molecular tools have been developed to determine the population structure of $X$. oryzae pv. oryzae. Restriction fragment length polymorphism (RFLP) analysis has been used for examining the genetic diversity and phylogenetic relationships of $X$. oryzae pv. oryzae occurring in Asia $(3,13,16)$. To expedite the analysis of a large number of samples, a simple and efficient DNA fingerprinting method based on polymerase chain reaction (PCR) using primers corresponding to the repetitive element IS 1112 has been developed (8). Outwardly directed oligonucleotides complementary to each end of the IS 1112 element were used to fingerprint pathogen strains, resulting in useful discrimination of Philippine strains of $X$. oryzae pv. oryzae $(7,8)$.

Based on molecular typing, a high level of diversity has been observed in the pathogen populations from different ricegrowing countries. Adhikari et al. (1) reported regional differentiation between $X$. oryzae pv. oryzae strains and possibly pathogen migration between countries in Asia. In the Philippines, a hierarchical analysis of strains from different agroecosystems along a $310-\mathrm{km}$ transect revealed a high degree of genetic differentiation between the pathogen populations among sites, indicating substantial geographical differentiation between the pathogen populations in different agroecosystems (3).
Contrasting results were reported on the genetic diversity of $X$. oryzae pv. oryzae strains from India. Yashitola et al. (24) reported the predominance of a closely related group of strains across the country, while others (19) reported a high level of genetic polymorphism detected among the strains from different regions of the country (19).

In India, the virulence spectrum of $X$. oryzae pv. oryzae has been analyzed using different sets of cultivars $(9,20)$. The number of pathotypes reported ranged from 2 to 11 depending on the number of differential cultivars used. Many of these differentials carry unknown genes for resistance or more than one gene for resistance. Despite extensive data on pathogen diversity, few studies examine the effectiveness of resistance genes against the range of pathotypes present in a location. Such an analysis would be important if the resistance genes are to be incorporated into commercial cultivars. This study is part of a regional effort to apply knowledge of pathogen population structure to the deployment of resistance genes. Similar experimental approaches were taken in several countries under the sponsorship of the Asian Rice Biotechnology Network at IRRI. Here we report the characterization of pathogen populations in eastern India and, based on this knowledge, we identify useful resistance genes that confer resistance to the contemporary pathogen populations.

\section{MATERIALS AND METHODS}

Plant materials and their culture. Seeds of rice cultivars or lines used were obtained from the International Rice Research Institute (IRRI), Philippines. Plants were grown under natural photoperiodic conditions $\left(24\right.$ to $34^{\circ} \mathrm{C}, 85 \%$ relative humidity) and total incident light of 475 $\mathrm{W} / \mathrm{m}^{2}$ (ranging from 283 to $583 \mathrm{~W} / \mathrm{m}^{2}$ ) measured with a solarimeter (OSK 76, Ogawa Seiki, Japan) in field plots under puddled conditions with spacing of 25 by $25 \mathrm{~cm}$ between rows and plants. The field plots were irrigated to maintain the plants under flooded conditions with 3 to $4 \mathrm{~cm}$ of standing water above the soil surface. The field plots were fertilized with urea $(\mathrm{N}$ at $80 \mathrm{~kg} / \mathrm{ha}$ ) in two split doses, $50 \%$ as basal and $50 \%$ at 15 days after transplanting.

Collection of infected leaf samples. Bacterial blight-infected leaf samples were 
collected from eight different sites (A-H) from three states of eastern India: Orissa (Cuttack district), Madhya Pradesh (Raipur district), and Uttar Pradesh (Faizabad district) (Table 1). The locations (district) of the sampling sites are separated from each other by several hundred kilometers. In each of these states, samples were collected from an experimental farm of the respective research station and from farmers' fields approximately 10 to $20 \mathrm{~km}$ away. Five fields, each planted with different cultivars, were sampled for sites A, D, $\mathrm{G}$, and $\mathrm{H}$. Two, three, four, and one fields for sites $\mathrm{B}, \mathrm{C}, \mathrm{E}$, and $\mathrm{F}$ were sampled, respectively. Disease samples were collected from three randomly selected places in each field and five hills located in a Wwalk fashion from a single place. Most of the hills sampled were $1 \mathrm{~m}$ apart. From each of the hills, five infected leaves were collected. Distances between sampling fields in a site varied depending on the cultivars grown and the incidence and severity of bacterial blight.

Isolation and maintenance of bacteria. One colony was picked per leaf sample and streaked on modified Wakimoto's medium (WF-P) (per liter: $20 \mathrm{~g}$ of sucrose, $5 \mathrm{~g}$ of peptone, $0.5 \mathrm{~g}$ of $\mathrm{Ca}\left[\mathrm{NO}_{3}\right]_{2} \cdot 4 \mathrm{H}_{2} \mathrm{O}, 1.82 \mathrm{~g}$ of $\mathrm{Na}_{2} \mathrm{HPO}_{4} \cdot 7 \mathrm{H}_{2} \mathrm{O}, 0.05 \mathrm{~g}$ of $\mathrm{FeSO}_{4}$. $7 \mathrm{H}_{2} \mathrm{O}, 18 \mathrm{~g}$ of agar). From leaves collected from each hill, a duplicate set of strains was obtained resulting in 10 strains from a place (five hills) and 30 strains from a field. Of these 30 strains, one isolate per hill was included in this study for a total of 15 strains per field planted to a single cultivar. Thus, 450 strains with approximately 15 to 75 strains per field were analyzed (Table 1).

For long-term storage, strains were maintained in $5 \%$ skim milk at $-20^{\circ} \mathrm{C}(15)$. The stored strains were revived and grown on modified WF-P for inoculation experiments and DNA extraction. For DNA extraction, cultures of $X$. oryzae pv. oryzae were grown overnight in $15 \mathrm{ml}$ of nutrient broth (per liter: $10 \mathrm{~g}$ of peptone, $3 \mathrm{~g}$ of beef extract [16]) at $28 \pm 2{ }^{\circ} \mathrm{C}$ on a rotary shaker (200 rpm).

Isolation of genomic DNA. Genomic DNA of $X$. oryzae pv. oryzae strains were prepared from 5-ml nutrient broth cultures grown overnight. The bacterial cells were collected and then lysed in $650 \mu \mathrm{l}$ of extraction buffer (100 mM Tris HCL, pH 8;

\section{2}

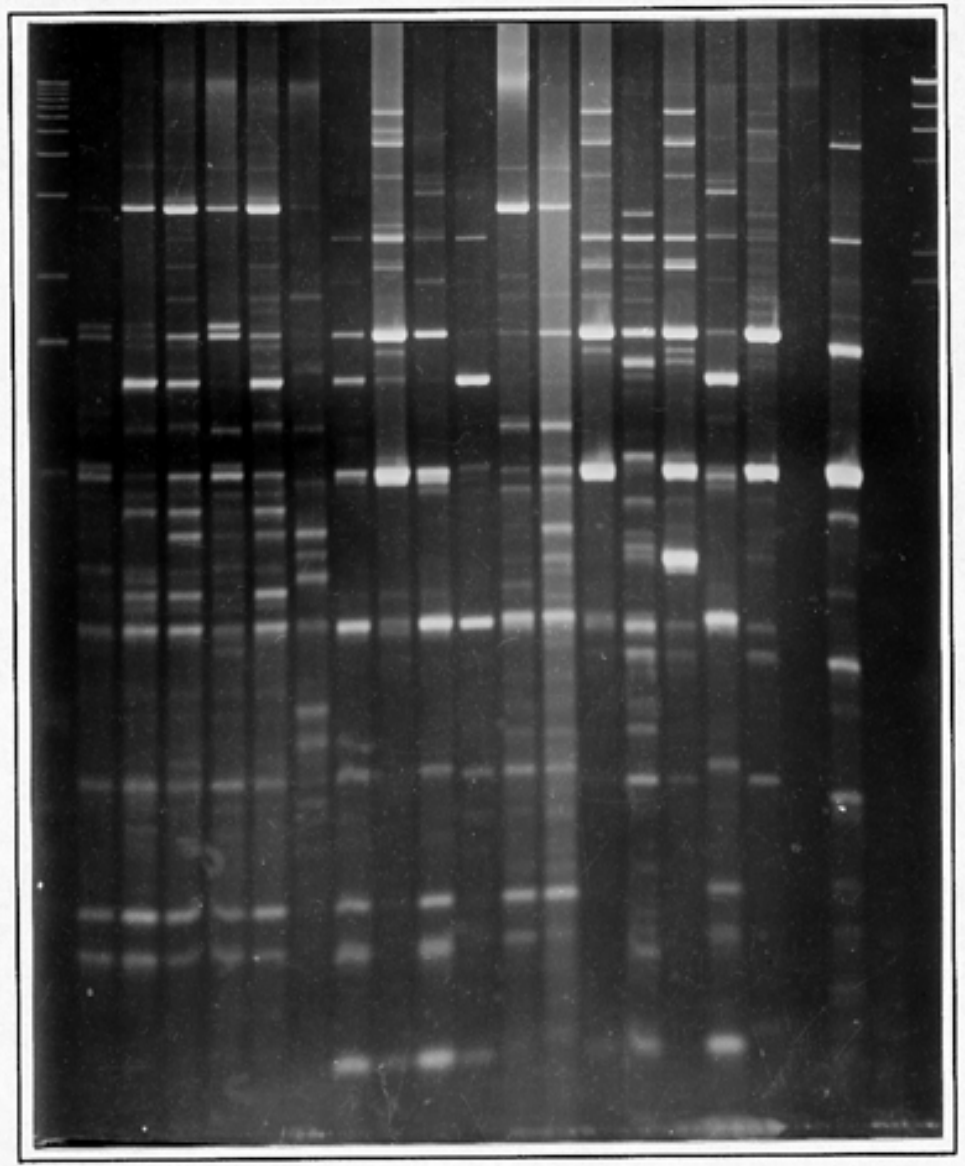

Fig. 1. Polymerase chain reaction fingerprint patterns of Xanthomonas oryzae pv. oryzae strains generated with IS1112-based primers (JEL1/JEL2). Lanes 2-18 contain the fingerprints of different haplotypes detected in the population from eastern India compared with Philippine strain PXO115 in lane 20. Lane 2, IAXO915; lane 3, IAXO945; lane 4, IAXO1025; lane 5, IAXO1027; lane 6, IAXO1031; lane 7, IAXO1032; lane 8, IAXO403; lane 9, IAXO409; lane 10, IAXO417; lane 11, IAXO247; lane 12, IAXO631; lane 13, IAXO644; lane 14, IAXO507; lane 15, IAXO474; lane 16, IAXO490; lane 17, IAXO304; lane 18, IAXO592; lane 20, PXO115. The DNA molecular size markers are on lane 1, 1-kb ladder, and on lane 22, HindIII-digested DNA.

Table 1. Characteristics of locations and rice cultivars grown in eastern India from which Xanthomonas oryzae pv. oryzae were collected and pathotypes detected $^{\mathrm{a}}$

\begin{tabular}{|c|c|c|c|c|c|c|c|}
\hline Ecosystem & Site & Farm category & $\begin{array}{c}\text { Location } \\
\text { (state/district) }\end{array}$ & $\begin{array}{l}\text { No. of fields } \\
\text { sampled }\end{array}$ & Planted $^{\mathrm{b}}$ & $\begin{array}{c}\text { No. of isolates } \\
\text { analyzed }\end{array}$ & Pathotypes \\
\hline Irrigated & $\begin{array}{l}\text { CRRI, Cuttack } \\
\text { (A) }\end{array}$ & Experimental farm & Orissa, Cuttack & 5 & $\mathrm{M} / \mathrm{T}$ & 75 & $\begin{array}{l}\text { XA-12, XA-59, } \\
\text { XA-63, XC-3, XH-1 }\end{array}$ \\
\hline Rainfed lowland & Anantapuar (B) & Farmers' fields & Orissa, Cuttack & 2 & $\mathrm{~T}$ & 30 & XA-59, XB-26, XE-2 \\
\hline Rainfed lowland & Fakirpara (C) & Farmers' fields & Orissa, Cuttack & 3 & $\mathrm{M}$ & 45 & XA-25, XA-59 \\
\hline Rainfed lowland & $\begin{array}{l}\text { Gandhi Univ., } \\
\text { Raipur (D) }\end{array}$ & Experimental farm & $\begin{array}{l}\text { Madhya Pradesh, } \\
\text { Raipur }\end{array}$ & 5 & $\mathrm{M} / \mathrm{T}$ & 75 & $\begin{array}{l}\text { XA-12, XA-13, } \\
\text { XA-59, XC-3 }\end{array}$ \\
\hline Rainfed lowland & Tulasibaradra (E) & Farmers' fields & $\begin{array}{l}\text { Madhya Pradesh, } \\
\text { Raipur }\end{array}$ & 4 & $\mathrm{M} / \mathrm{T}$ & 60 & XA-13 \\
\hline Rainfed lowland & Cherikedi (F) & Farmers' fields & $\begin{array}{l}\text { Madhya Pradesh, } \\
\text { Raipur }\end{array}$ & 1 & $\mathrm{~T}$ & 15 & XA-13 \\
\hline Rainfed lowland & $\begin{array}{l}\text { Dev Univ., } \\
\text { Masodha (G) }\end{array}$ & Experimental farm & $\begin{array}{l}\text { Uttar Pradesh, } \\
\text { Faizabad }\end{array}$ & 5 & $\mathrm{M} / \mathrm{T}$ & 75 & XA-13, XH-1, XC-3 \\
\hline Rainfed lowland & $\begin{array}{l}\text { Kalyanbhadarsha } \\
\text { (H) }\end{array}$ & Farmers' fields & $\begin{array}{l}\text { Uttar Pradesh, } \\
\text { Faizabad }\end{array}$ & 5 & $\mathrm{M} / \mathrm{T}$ & 75 & XA-13, XH-1 \\
\hline
\end{tabular}

${ }^{a}$ Site $=$ research institute or village; CRRI = Central Rice Research Institute; Gandhi Univ. = Indira Gandhi Agricultural University; and Dev Univ. = Crop Research Station, Narendra Dev University of Agriculture and Technology.

${ }^{\mathrm{b}}$ Rice planted; $\mathrm{M}=$ modern high-yielding cultivars and $\mathrm{T}=$ traditional tall cultivars. 
$100 \mathrm{mM}$ EDTA; $250 \mathrm{mM} \mathrm{NaCl} ; 1 \%$ sodium dodecyl sulfate [SDS], wt/vol; $1 \%$ polyvinylpyrrolidone [PVP]-40, wt/vol) at $65^{\circ} \mathrm{C}$ for $30 \mathrm{~min}$. DNA was isolated using a modified method with $100 \mu \mathrm{l}$ of potassium acetate (3M potassium, $5 \mathrm{M}$ acetate, $\mathrm{pH}$ 4.8) and precipitated with isopropanol (7). The DNA was dissolved in sterile distilled water and relative concentration of DNA present in the solution was visually quantified by coelectrophoresis with DNA standards after staining with ethidium bromide.

PCR fingerprinting. Amplification was performed as described by George et al. (8) in a $25-\mu \mathrm{l}$ volume containing 50 pmoles each of the two opposing primers, JEL 1 (5'CTCAGGTCAGGTCGCC $\left.3^{\prime}\right)$ and JEL2 (5'GCTCTACAATCGTCCGC3') complementary to each end of IS1112, $20 \mathrm{ng}$ of genomic DNA, $185 \mu \mathrm{M}$ each of four dNTPs, approximately 2.5 units of Taq polymerase in a standard incubation buffer (Boehringer Mannheim) supplemented with $10 \%$ dimethylsulfoxide (vol/vol), and $7.5 \mu \mathrm{l}$ of Tris- $\mathrm{HCl}(\mathrm{pH} 9.5)$. The reaction mixture was overlaid with one drop of mineral oil, initially denatured for $1 \mathrm{~min}$ at $94^{\circ} \mathrm{C}$, and then subjected to 30 cycles of PCR $\left(10 \mathrm{~s}\right.$ of denaturation at $94^{\circ} \mathrm{C}, 1 \mathrm{~min}$ of annealing at $62^{\circ} \mathrm{C}$, and 8 min of extension at $65^{\circ} \mathrm{C}$ ), and a final extension for 8 min at $65^{\circ} \mathrm{C}$ using a Thermal Cycler (PTC100) manufactured by MJ Research (Watertown, MA). Aliquots of $15 \mu \mathrm{l}$ of the reaction mixture containing the PCR products were loaded in a gel containing $0.5 \%$ agarose and $0.75 \%$ Synergel (Diversified Biotech, Newton, MA) in $0.5 \times$ Tris-borate buffer. Amplified products were resolved by electrophoresis for $7 \mathrm{~h}$ at $125 \mathrm{~V}$, stained with ethidium bromide, and then photographed using Polaroid type 665 film.

The banding pattern of each isolate was recorded in binary form, 1 representing the presence and 0 the absence of each band. Similarity coefficients were calculated for all pairwise combinations of haplotypes using Dice's coefficient $(21,23)$. A dendrogram was generated with the SAHN (sequential, agglomerative, hierarchical, and nested clustering methods) program of NTSYS-pc (version 1.70; Exeter Software, Setauket, NY) using the unweighted pairgroup method using arithmetic averages (UPGMA; 21). Bootstrap analysis using the computer program Winboot (23) was used to assess the robustness of the groupings produced by cluster analysis. The phenograms were reconstructed 2,000 times by repeated sampling with replacement, and the frequency with which a particular grouping formed was used as a measure of the strength of the grouping $(6,10,23)$.

Table 2. Distribution of haplotypes of Xanthomonas oryzae pv. oryzae in three regions in eastern India

\begin{tabular}{lccc}
\hline Haplotype & Orissa & Madhya Pradesh & Uttar Pradesh \\
\hline IAXO915 & 0 & 0 & 57 \\
IAXO945 & 0 & 0 & 33 \\
IAXO1025 & 0 & 21 & 9 \\
IAXO1027 & 0 & 37 & 10 \\
IAXO1031 & 0 & 41 & 15 \\
IAXO1032 & 0 & 34 & 21 \\
IAXO403 & 26 & 8 & 5 \\
IAXO409 & 12 & 4 & 0 \\
IAXO417 & 9 & 0 & 0 \\
IAXO247 & 4 & 0 & 0 \\
IAXO631 & 7 & 0 & 0 \\
IAXO644 & 9 & 0 & 0 \\
IAXO507 & 19 & 0 & 0 \\
IAXO474 & 6 & 0 & 0 \\
IAXO490 & 30 & 5 & 0 \\
IAXO304 & 3 & 0 & 0 \\
IAXO592 & 25 & 0 & 0 \\
Haplotype (n) & 11 & 7 & 7 \\
Total strains (n) & 150 & 150 & 150 \\
$\mathrm{H}_{\mathrm{T}}{ }^{\mathrm{a}}$ & 0.87 & 0.79 & 0.77 \\
\hline
\end{tabular}

${ }^{\mathrm{a}} \mathrm{H}_{\mathrm{T}}=$ haplotypic diversity index.
Diversity and population structure. Partitioning of the diversity was estimated using analysis of molecular variance (AMOVA, Arlequin software; 5). This estimates genetic structure inferred by analysis of molecular variance from PCR data and examines the amount and pattern of genetic subdivisions in a region. The variance components among populations $(a)$ and within populations (b) are defined respectively as: $a=n \sigma_{a}^{2}+$ $\sigma_{b}^{2}$ and $b=\sigma_{b}^{2}$, where $n$ and fixation index $\left(\mathrm{F}_{\mathrm{ST}}\right)$ are defined by $n=(N-$ $\left.\left[\Sigma N^{2} / N\right]\right) / P-1$ and $\mathrm{F}_{\mathrm{ST}}=\sigma_{a}{ }^{2} / \sigma_{\mathrm{T}}{ }^{2}$, where $N$ is the total number of gene copies and $P$ is the total number of populations. The $\sigma_{a}{ }^{2}$ and $\mathrm{F}_{\mathrm{ST}}$ are tested by permuting haplotypes among populations.

The haplotypic diversity index $\left(\mathrm{H}_{\mathrm{T}}\right)$ for each state in eastern India was determined

\section{Similarity coefficient}

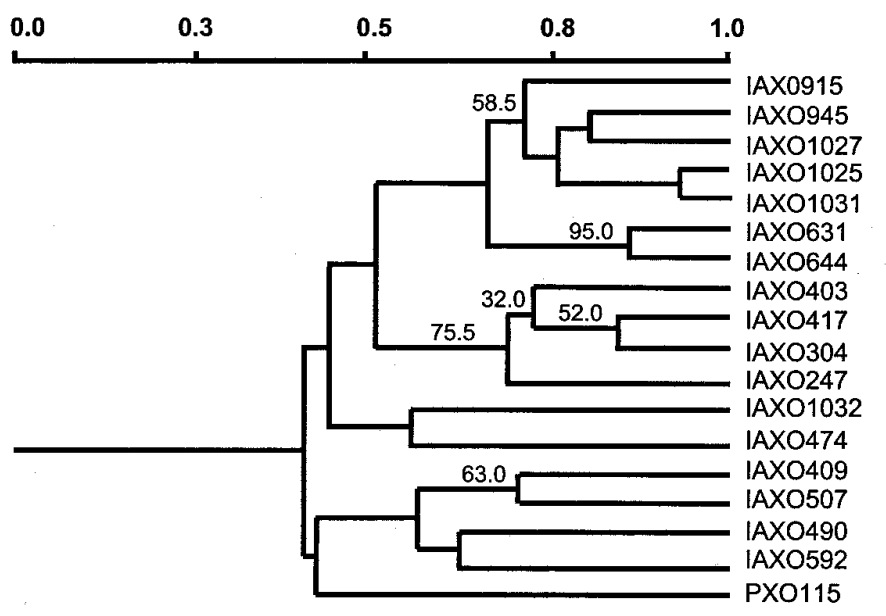

\begin{tabular}{|c|c|c|c|c|c|c|c|c|}
\hline \multirow[b]{2}{*}{ Lineage } & & \multicolumn{7}{|c|}{ Reaction to host differentials } \\
\hline & athotyp & $X a 3$ & as & $x a$ & Xa7 & Xa1 & a & Xa21 \\
\hline $\mathrm{XL}-1$ & $\mathrm{XH}-1$ & $\mathbf{R}$ & $\mathrm{R}$ & $\mathrm{R}$ & $\mathrm{R}$ & $\mathbf{R}$ & $\mathrm{R}$ & $\mathrm{R}$ \\
\hline$X L-2$ & $X \mathrm{H}-1$ & $\mathrm{R}$ & $\mathbf{R}$ & $\mathrm{R}$ & $\mathrm{R}$ & $\mathrm{R}$ & $\mathrm{R}$ & $\mathrm{R}$ \\
\hline$X \mathrm{~L}-2$ & XA-13 & $\mathrm{s}$ & $s$ & $s$ & $\mathbf{R}$ & $R$ & S & $\mathrm{s}$ \\
\hline$X \mathrm{~L}-2$ & XA-13 & $s$ & $S$ & $S$ & $\mathrm{R}$ & $\mathrm{R}$ & $\mathrm{S}$ & $S$ \\
\hline$X L-2$ & XA-13 & $s$ & $S$ & $S$ & $\mathrm{R}$ & $\mathrm{R}$ & $S$ & $s$ \\
\hline XL-3 & XB-26 & $\mathrm{R}$ & $S$ & $\mathrm{R}$ & $\mathrm{R}$ & $\mathrm{s}$ & $\mathrm{S}$ & $\mathrm{R}$ \\
\hline XL-3 & XE-2 & $\mathrm{R}$ & $\mathrm{R}$ & $\mathrm{R}$ & $\mathrm{R}$ & $S$ & $S$ & $\mathbf{R}$ \\
\hline$X \mathrm{~L}-4$ & $x C-3$ & $\mathrm{R}$ & $\mathrm{R}$ & s & $\mathrm{s}$ & $\mathrm{s}$ & $\mathrm{R}$ & $\mathrm{s}$ \\
\hline$X L-5$ & XA-63 & $s$ & $\mathrm{R}$ & $\mathrm{R}$ & $\mathrm{R}$ & $\mathrm{R}$ & $\mathrm{R}$ & $S$ \\
\hline XL-5 & $x C-3$ & $\mathrm{R}$ & $\mathrm{R}$ & $S$ & $S$ & $\mathrm{~s}$ & $\mathrm{R}$ & $s$ \\
\hline$X \mathrm{~L}-6$ & $\mathrm{XH}-1$ & $\mathrm{R}$ & $\mathrm{R}$ & $\mathrm{R}$ & $\mathrm{R}$ & $\mathrm{R}$ & $\mathrm{R}$ & $\mathrm{R}$ \\
\hline XL-7 & XA-13 & $S$ & $S$ & $S$ & $\mathrm{R}$ & $\mathrm{R}$ & $S$ & $\mathrm{~s}$ \\
\hline XL-8 & XA-12 & $\mathrm{s}$ & $S$ & $S$ & $\mathrm{R}$ & $S$ & $\mathrm{R}$ & $\mathrm{R}$ \\
\hline$X L-9$ & XA-59 & $S$ & $\mathrm{R}$ & $\mathrm{R}$ & $\mathrm{R}$ & $S$ & $\mathrm{R}$ & $s$ \\
\hline$X L-10$ & XA-25 & $S$ & $S$ & $\mathrm{R}$ & $R$ & $\mathrm{~S}$ & $\mathrm{~S}$ & $\mathrm{~S}$ \\
\hline XL-11 & XA-12 & $\mathrm{S}$ & $S$ & $S$ & $\mathrm{R}$ & $\mathrm{s}$ & $\mathbf{R}$ & $\mathrm{R}$ \\
\hline$X L-12$ & XA-59 & $S$ & $\mathrm{R}$ & $\mathrm{R}$ & $\mathrm{R}$ & $R$ & $\mathrm{R}$ & s \\
\hline - & - & - & - & - & - & - & & - \\
\hline
\end{tabular}

Fig. 2. Dendrogram constructed with unweighted pair-group method using arithmetic averages using polymerase chain reaction-based fingerprinting of 450 strains of Xanthomonas oryzae pv. oryzae from three eastern states of India. The bootstrap values reflect the strength of the grouping based on percentage of iterations in which the major groups were formed. The corresponding reaction of each differential cultivar across haplotypes are indicated as $\mathrm{R}$ ( $<4 \mathrm{~cm}$ lesion length) or S ( $>4 \mathrm{~cm}$ lesion length). 
following the formula of Nei (15) using Arlequin software (5):

$$
H_{T}=[n /(n-1)] \times\left(1-\sum_{i=1}^{k} X_{i}^{2}\right)
$$

where $n=$ total number of haplotypes in the population, $k=$ total number of haplotypes in the site, and $X_{i}=$ sample frequency of the $i$ th haplotype.

Evaluation of resistance. All plant inoculations were done in the greenhouse or in the field. To maintain aggressiveness, strains used for inoculation were passed through susceptible cv. Karuna, which was raised in pots in the nethouse. The top three to four leaves of 45-day-old fieldgrown plants were clip inoculated with a cell suspension (adjusted to $10^{8} \mathrm{CFU} / \mathrm{ml}$ ) prepared from 48-h-old cultures grown in WF-P broth. A randomized complete block factorial design was used for inoculation experiments. For each cultivar-strain combination, three to four leaves of a plant were inoculated per replicate, and each test was replicated three times. Lesion lengths were measured 14 days postinoculation. For typing of disease response, each plant was classified as resistant if the mean lesion length was between 0 and $4 \mathrm{~cm}$. Plants with lesion lengths $>4 \mathrm{~cm}$ were classified qualitatively as susceptible.

The plant materials included nearisogenic lines IRBB3 (Xa3), IRBB4 (Xa4), IRBB5 (xa5), IRBB7 (Xa7), IRBB10 (Xa10), IRBB13 (xa13), and IRBB21 (Xa21) along with a set of standard check cultivars (IR24 and Karuna, susceptible; and Malagkit Sungsong, resistant). Each near-isogenic line carries a defined resistance gene backcrossed into susceptible cv. IR24 (18). In addition, the reaction of a set of three gene pyramids (AY 4+5-2 $[\mathrm{Xa} 4+$ $x a 5], \mathrm{NH} 11-21-1-3[x a 5+X a 21]$, and $\mathrm{NH} 21-37-1-1[\mathrm{Xa} 4+x a 5+X a 21])$ in IR24 background to all the strains was also evaluated $(11,25)$. Differences in lesion lengths on near-isogenic lines and gene pyramids were analyzed by analysis of variance (ANOVA).

\section{RESULTS}

DNA fingerprints and population substructuring. PCR fingerprinting of 450 strains showed clearly distinct banding patterns among groups of $X$. oryzae $\mathrm{pv}$. oryzae strains (Fig. 1). DNA fingerprints consisting of 15 to 35 bands were generated with the IS1112-based PCR primers. The largest DNA fragment detected was approximately $7.0 \mathrm{~kb}$ and the smallest was $100 \mathrm{bp}$. There were 64 band positions scored in the PCR-based fingerprints. Seventeen distinct DNA banding profiles (haplotypes) were defined.

The genetic relationships among strains and the banding patterns were analyzed by cluster analysis. At $45 \%$ level, four larger clusters were observed, containing a total of 17 haplotypes from India and one Philippine isolate, PXO115, forming a distinct group by itself (Fig. 2). At $80 \%$ similarity level, 12 lineages were defined among all strains from the three states (Orissa, Madhya Pradesh, and Uttar Pradesh). The distribution of representative haplotypes and their relative frequencies in three states of eastern India is shown in Table 2 and Figure 3. The Orissa population was most diverse, consisting of 11 out of 17 haplo- types detected from three regions. The populations of Uttar Pradesh and Madhya Pradesh appeared more similar, whereas the Orissa population had unique haplotypes. Partitioning of the variation by AMOVA showed that the regional populations were structured with $25 \%$ of the variation attributed to differences among populations at each region (Table 3 ).

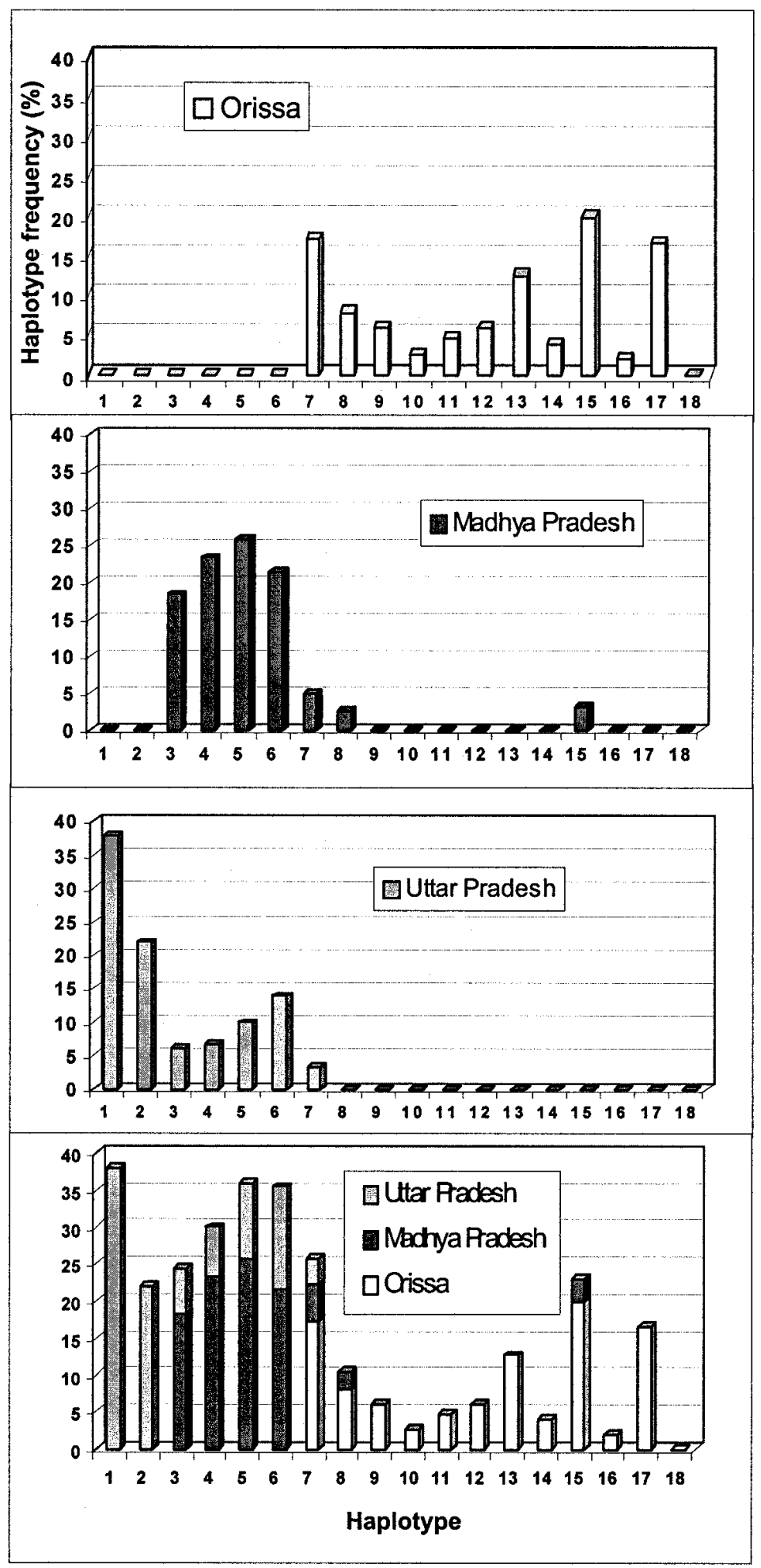

Fig. 3. Relative frequency (\%) of haplotype distribution of Xanthomonas oryzae pv. oryzae in three regions of eastern India. 
Collections from a given site tended to consist of related haplotypes, and some haplotypes were collected from a single site only. Collections from an experimental farm (e.g., in Orissa) showed greater diversity, perhaps due to cultivation of diverse rice genotypes. On the other hand, collections from the farmers' fields were less diverse, probably a reflection of the few cultivars planted in farmers' fields. Strains obtained from modern high-yielding cultivars in Fakirpara exhibited greater genetic variation when compared with those from traditional cultivars in Anantapuar in Orissa. A similar trend was also seen between haplotypes obtained from Tulasibaradra fields, planted with both modern and traditional cultivars in Madhya Pradesh, and Cherikedi fields, planted with traditional cultivars only.

Virulence diversity. Like the diversity revealed by DNA fingerprint patterns, virulence analysis also exhibited a high level of diversity among the pathogen

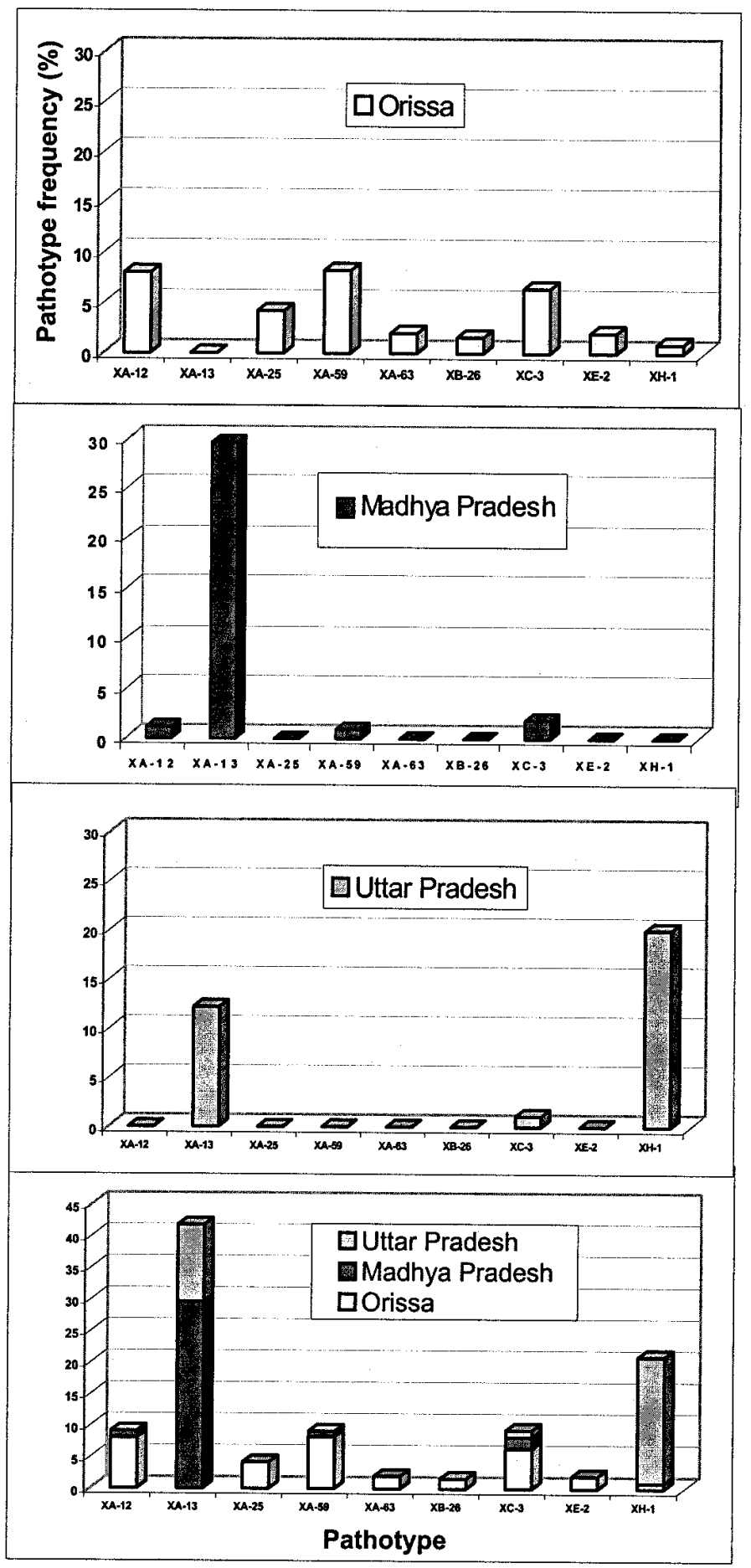

Fig. 4. Relative frequency (\%) of pathotype distribution of Xanthomonas oryzae pv. oryzae in three regions of eastern India.

strains from eastern India. Using a differential set consisting of near-isogenic lines and two check cultivars (Karuna and Malagkit Sungsong), 450 strains of $X$. oryzae pv. oryzae were grouped into nine pathotypes (Fig. 2). This diversity is influenced by the site of collection and cultivars sampled (Fig. 4 and Table 1). The number of pathotypes occurring in the two experimental farms at the Central Rice Research Institute (CRRI) in Cuttack and at Indira Gandhi Agricultural University (IGAU) in Raipur was greater than that observed in farmers' fields. The detection of only two pathotypes at the Narendra Development University of Agriculture and Technology (NDUAT) Crops Research Station in Masodha was, however, an exception in comparison with pathotypes from CRRI and IGAU. This may be due to the fact that the sampling of diseased leaves was restricted only to long-duration crops toward the end of the wet season, by which time the early-maturing crops were already harvested. This situation reduces the probability of collecting more samples that would most likely contribute to the diversity of the population in the research station at Masodha.

Although a few pathotypes (XA-25, XA-63, XB-26, and XE-2) fall within specific lineages (at $80 \%$ similarity level), the relationship among the haplotypes, lineages, and pathotypes appears to be complex (Fig. 2). For example, pathotype $\mathrm{XH}-1$ was found in three lineages and some other pathotypes (XA-12, XA-13, XA-59, and $\mathrm{XC}-3$ ) were found in two lineages each. In addition, similar haplotypes exhibited different phenotypes on the same set of nearisogenic lines as found in the diagnostic set of isolates. Based on these relationships, we selected 10 strains that represent haplotypic and pathotypic diversity to evaluate resistance genes.

Effectiveness of resistance genes. Analysis of disease reaction showed that each near-isogenic line was susceptible to one or more of the representative virulent strains in India. The genes $X a 7$ and $x a 5$, conferring resistance to 8 out of the 10 haplotypes, and $\mathrm{Xa} 4$, resistant to 7 out of 10 haplotypes, showed the broadest spectrum of resistance, whereas Xall and Xal4 showed limited range of resistance, conferring resistance to only 3 to 4 haplotypes. $X a 21$, previously reported to have a higher spectrum of resistance, is only resistant to five haplotypes. However, the degree of susceptibility varied; IRBB21 only showed moderate susceptibility $(2.5$ to $9.2 \mathrm{~cm})$ to all haplotypes.

From the perspective of pathogen virulence, the most common haplotypes (IAXO1031, pathotype XA-13 and 25.9\% in Madhya Pradesh; IAXO490, pathotype XA-12 and $20 \%$ in Orissa) can overcome $\mathrm{Xa3}, \mathrm{Xa4}$, and $x a 5$ (Fig. 2). Haplotype IAXO1031 is also virulent to xa13 and 
$X a 21$, whereas $X a 10$ can also be overcome by haplotype IAXO490. Pathotypes XA-12 and XA-13 were virulent to four and five lines (Xa3, Xa4, xa5, xa13, and $\mathrm{Xa21}$ ), respectively, although the degree of aggressiveness varied. No single haplotype was virulent to all $X a$ genes tested.

Gene pyramids with three gene combinations (AY 4+5-2 [Xa-4 + xa-5], NH1217-2-4 [xa-5 + Xa-21], and NH24-10-1-3 $[X a-4+x a-5+X a-21])$ were resistant to all the pathotypes detected in this study (Table 4). Lesion lengths on gene pyramids were significantly shorter than single-gene nearisogenic lines even though the gene pyramids were inoculated with strains that were virulent to individual $X a$ genes. ANOVA shows that the gene pyramids were significantly more resistant to all pathotypes than their respective individual $\mathrm{Xa}$ gene (Table 4). For example, complementary gene action was observed in $X a 4(5.7 \mathrm{~cm})$ or $x a 5$ $(4.4 \mathrm{~cm})$ and $X a 21(9.2 \mathrm{~cm})$ where both single genes are susceptible to IAXO34, but the two-gene pyramids $(\mathrm{Xa} 4+x a 5$ and $x a 5$ $+X a 21)$ show significantly shorter lesions.

\section{DISCUSSION}

We characterized 450 strains of $X$. oryzae pv. oryzae collected from three regions in eastern India, employing both DNA fingerprinting and virulence analysis. This comprehensive analysis enables us to select representative pathogen strains to identify the appropriate resistance genes for use in the region.

PCR-based fingerprinting differentiated the pathogen collection into 17 haplotypes that formed 12 lineages at $80 \%$ similarity level. The observed substructuring of the pathogen population may reflect differences in the germ plasm used in the regions, which consist of unique modern and traditional cultivars. For example, Mahsuri, a traditional cultivar, is commonly cultivated in both Madhya Pradesh and Uttar Pradesh, whereas modern cultivars such as Swarna and traditional Safri17 are cultivated only in Madhya Pradesh. In Uttar Pradesh, a different set of modern (Jallahari and Sarjoo-52) and traditional (Chaikia-59 and Jalmagna) cultivars predominate. The cultivars sampled in Orissa are most diverse, including a variety of modern (Panidhan, Moti, Lunisree, and Udya) and traditional (Boithalpokhia, Cuttack Chandi, Rathna Chandi, and Nallifarm) cultivars. It has been suggested that cultivar differences exert strong influence on the $X$. oryzae $p v$. oryzae pathogen

Table 3. Analysis of molecular variance among and within populations of Xanthomonas oryzae pv. oryzae in eastern India

\begin{tabular}{lrccc}
\hline Source of variation & df & Sum of squares & Variance components & $\begin{array}{c}\text { Percentage of } \\
\text { variation }\end{array}$ \\
\hline Among populations & 2 & 886.234 & $2.847 \mathrm{Va}$ & 25.0 \\
Within populations & 455 & $3,884.913$ & $8.539 \mathrm{Vb}$ & 75.0 \\
Total & 457 & $4,771.146$ & $\ldots$ & $\ldots$ \\
Fixation index & $\ldots$ & 0.250 & $\ldots$ & $\ldots$ \\
\hline
\end{tabular}

populations $(2,3)$. In the Philippines, $X$. oryzae $p v$. oryzae strains are distributed uniquely in three different agroecosystems (i.e., highland, transition zone, and the lowland) where the cultivars are thought to play a significant role in the differentiation of the pathogen population (3).

Although Leach et al. (13) detected a strong association between RFLP types and pathotype groupings, the relationship among lineages and pathotypes appears to be complex (16). A similar result was observed for the relationship among lineages and pathotypes in eastern India. Some pathotypes were found in several lineages and some lineages consisted of several pathotypes. Thus, although molecular typing is useful in revealing groups of genetically related strains, there is yet no perfect prediction for virulence characteristics. Nevertheless, the efficiency and precision of virulence analysis can be enhanced with rapid PCR fingerprinting of the pathogen population, thus limiting the number of strains to be handled for virulence analysis.

Evaluation of the single-gene nearisogenic lines has enabled us to anticipate the potential problem of using a single resistance gene over a large area. Although many resistance genes were found to be useful in different locations, a small proportion of the pathogen population was found to be compatible to individual genes. A relevant example is the detection of strains compatible to $\mathrm{Xa21}$, which was reported to have broad-spectrum resistance based on greenhouse tests (22) and, presumably, to be effective in many regions in India (4). Devadath (4) evaluated the wild rice strain carrying $\mathrm{Xa} 21$ at CRRI, Cuttack

Table 4. Reaction of individual gene and gene pyramids for bacterial blight resistance to ten diagnostic strains of Xanthomonas oryzae pv. oryzae from eastern India

\begin{tabular}{|c|c|c|c|c|c|c|c|c|c|c|c|c|}
\hline \multirow{3}{*}{$\begin{array}{l}\text { Near-isogenic } \\
\text { line/pyramid } \\
\text { (Xa gene) }\end{array}$} & \multicolumn{10}{|c|}{ Lesion length $(\mathrm{cm})$ with strain: ${ }^{a}$} & \multirow{2}{*}{\multicolumn{2}{|c|}{ Resistance $^{\mathrm{b}}$}} \\
\hline & \multirow{2}{*}{$\begin{array}{r}\text { IAXO34 } \\
\text { (XL-11) } \\
\text { [XA-1] }\end{array}$} & \multirow{2}{*}{$\begin{array}{c}\text { IAXO36 } \\
\text { (XL-5) } \\
\text { [XA-59] }\end{array}$} & \multirow{2}{*}{$\begin{array}{c}\text { IAXO71 } \\
\text { (XL-4) } \\
{[\text { XA-28] }}\end{array}$} & \multirow{2}{*}{$\begin{array}{c}\text { IAXO90 } \\
\text { (XL-7) } \\
{[\text { XA-52] }}\end{array}$} & \multirow{2}{*}{$\begin{array}{c}\text { IAXO 100 } \\
\text { (XL-9) } \\
\text { [XA-36] }\end{array}$} & \multirow{2}{*}{$\begin{array}{c}\text { IAXO 135 } \\
\text { (XL-6) } \\
\text { [XE-3] }\end{array}$} & \multirow{2}{*}{$\begin{array}{c}\text { IAXO 139 } \\
\text { (XL-6) } \\
\text { [XF-1] }\end{array}$} & \multirow{2}{*}{$\begin{array}{l}\text { IAXO 146 } \\
\text { (XL-9) } \\
\text { [XE-3] }\end{array}$} & \multirow{2}{*}{$\begin{array}{c}\text { IAXO } 635 \\
\text { (XL-3) } \\
\text { [XB-26] }\end{array}$} & \multirow{2}{*}{$\begin{array}{c}\text { IAXO } 665 \\
\text { (XL-1) } \\
{[\mathrm{XF}-2]}\end{array}$} & & \\
\hline & & & & & & & & & & & $\mathbf{R}$ & $\mathbf{S}$ \\
\hline IRBB1 $(X a 1)$ & 10.5 & 2.7 & 2.4 & 5.2 & 5.5 & 2.4 & 5.9 & 6.7 & 2.7 & 2.2 & 5 & 5 \\
\hline IRBB3 (Xa3) & 5.4 & 6.6 & 6.9 & 4.7 & 6.3 & 2.0 & 2.2 & 2.5 & 2.4 & 2.7 & 5 & 5 \\
\hline IRBB4 (Xa4) & 5.7 & 2.6 & 6.7 & 3.3 & 2.6 & 2.8 & 2.9 & 2.9 & 5.2 & 2.6 & 7 & 3 \\
\hline IRBB5 ( $x a 5)$ & 4.4 & 2.5 & 2.5 & 2.6 & 6.1 & 2.8 & 2.6 & 2.7 & 2.9 & 2.8 & 8 & 2 \\
\hline IRBB7 (Xa7) & 5.2 & 3.2 & 3.4 & 2.7 & 5.1 & 2.8 & 2.4 & 2.9 & 2.7 & 2.4 & 8 & 2 \\
\hline IRBB8 ( $x a 8)$ & 4.8 & 8.0 & 5.0 & 2.9 & 8.5 & 3.0 & 2.5 & 2.3 & 4.1 & 2.8 & 5 & 5 \\
\hline IRBB10 (Xa10) & 5.7 & 4.5 & 5.5 & 2.5 & 5.5 & 5.4 & 3.0 & 7.1 & 6.2 & 2.2 & 3 & 7 \\
\hline IRBB11 (Xa11) & 6.5 & 3.1 & 5.0 & 3.2 & 8.1 & 3.3 & 2.6 & 2.3 & 4.3 & 2.7 & 6 & 4 \\
\hline IRBB13 (xa13) & 5.7 & 3.0 & 3.9 & 6.5 & 2.7 & 2.6 & 4.9 & 2.8 & 4.9 & 7.7 & 5 & 5 \\
\hline IRBB14 (Xa14) & 5.4 & 2.5 & 3.1 & 2.2 & 2.7 & 5.7 & 5.5 & 6.1 & 1.9 & 2.8 & 6 & 4 \\
\hline IRBB21 (Xa21) & 9.2 & 8.7 & 3.0 & 2.5 & 2.8 & 7.8 & 7.9 & 6.2 & 3.0 & 2.6 & 5 & 5 \\
\hline AY $4+5-2$ & & & & & & & & & & & & \\
\hline$(X a 4+x a 5)$ & 3.0 & 2.0 & 1.5 & 1.5 & 1.4 & 1.4 & 2.0 & 0.8 & 1.0 & 3.0 & 10 & 0 \\
\hline $\begin{array}{l}\text { NH11-21-1-3 } \\
(x a 5+X a 21)\end{array}$ & 1.5 & 1.3 & 2.2 & 1.5 & 0.9 & 1.8 & 1.3 & 1.5 & 0.5 & 35 & 10 & 0 \\
\hline NH21-37-1-1 & & & & & & & & & & & & \\
\hline $\begin{array}{l}(\mathrm{x} a 4+x a 5+X a 21) \\
\text { IR24 }\end{array}$ & 1.1 & 3.2 & 2.0 & 1.5 & 1.5 & 1.7 & 2.2 & 1.3 & 1.8 & 1.9 & 10 & 0 \\
\hline (recurrent parent) & 5.0 & 4.9 & 5.7 & 4.5 & 5.8 & 2.6 & 3.6 & 6.7 & 6.0 & 4.7 & 2 & 8 \\
\hline Karuna (S) & 6.8 & 10.3 & 7.3 & 9.6 & 9.3 & 9.7 & 6.8 & 9.5 & 9.6 & 8.6 & 0 & 10 \\
\hline
\end{tabular}

${ }^{a}$ Strain code of the diagnostic isolate; designation in parentheses refers to lineage grouping of the diagnostic isolate and designation in brackets refers to pathotype grouping of the diagnostic isolate. Mean of three replications; least significant difference $=2.05(5 \%), 3.11(1 \%)$.

${ }^{\mathrm{b}}$ Qualitative spectrum of resistance: number of resistant $(\mathrm{R})$ and susceptible $(\mathrm{S})$ reactions across diagnostic strains; $\mathrm{R}=<4.0 \mathrm{~cm}$ and $\mathrm{S}=>4.0 \mathrm{~cm}$. 
with very diverse sets of isolates originating from different parts of India, and it was found to be highly resistant. In this study, however, a diverse collection of contemporary isolates from three regions of eastern India that have not been used earlier to test the spectrum of resistance of $\mathrm{Xa2l}$ were used to evaluate $X a 21$. Indeed, a higher frequency $(50 \%)$ of $X$. oryzae pv. oryzae strains virulent to $X a 21$ was present in the contemporary pathogen population. The detection of compatible pathogen strains does not necessarily preclude the use of the corresponding resistance genes; rather, it provides an anticipatory approach to combine suitable genes. However, since incompatible interaction (resistance) is usually epistatic to compatibility (susceptibility), the presence of one resistance gene would mask the presence of other resistance genes in the same genotype. This poses a limitation in determining the range of pathogen virulence in the field, and hinders efforts to incorporate multiple resistance genes in elite cultivars.

In this study, we evaluated a set of lines with two- or three-gene combinations in IR24 background, Xa4 + xa5, xa5 + Xa21, and $X a 4+x a 5+X a 21$, along with their individual genes, for their reaction to all the strains. Field inoculation data indicated the effectiveness of some of the individual genes with the broadest spectrum shown by $x a 5$ and $X a 7$. Interestingly, all lines with two- and three-gene combinations were resistant to all the contemporary pathotypes in eastern India, presumably due to the complementary action of the resistance genes (25). Similar observations also were made in parallel studies conducted through the Asian Rice Biotechnology Network in China (26), Indonesia (M. Bustamam, Research Institute for Food Crops Biotechnology, Indonesia, personal communication), and in the Punjab region of India (K. Singh, Punjab Agricultural University, personal communication).

Likewise, in Nepal, a similar set of two$(\mathrm{AY} 4+5[\mathrm{Xa} 4+x a 5])$ and three-gene $(\mathrm{NH} 21[\mathrm{Xa} 4+x a 5+x a 13]$ and $\mathrm{NH} 24$ $[X a 4+x a 5+X a 21])$ combinations were effective against the local pathogen population (1). However, seven near-isogenic lines carrying single genes ( $x a 5, \mathrm{Xa} 7, x a 8$, and $\mathrm{Xa21}$ ) were susceptible to all strains used in their study. Thus, the effectiveness of single genes varies in different regions in Asia. To have an effective deployment of resistant cultivars, regional information on the performance of individual genes or in combination is therefore a prerequisite.
In conclusion, our study revealed the existence of a diverse population of $X$. oryzae pv. oryzae in eastern India. It also provides the foundation to monitor predominant strains in different target regions. The identification of useful resistance genes through virulence analysis will support a gene deployment approach to managing the disease using resistant cultivars.

\section{ACKNOWLEDGMENTS}

We thank G. S. Khush, IRRI, Philippines, for providing the seeds of near-isogenic lines and gene combinations; and V. S. Trimurthy, Indira Gandhi Agricultural University, and C. H. Mishra, Crop Research Station, Narendra Dev University of Agriculture and Technology, for their help rendered in sample collections.

\section{LITERATURE CITED}

1. Adhikari, T. B., and Basnyat, R. C. 1999. Virulence of Xanthomonas oryzae pv. oryzae on rice lines containing single resistance genes and gene combinations. Plant Dis. 83:46-50.

2. Adhikari, T. B., Vera Cruz, C. M., Zhang, Q., Nelson, R. J., Skinner, D. Z., Mew, T. W., and Leach, J. E. 1995. Genetic diversity of Xanthomonas oryzae pv. oryzae in Asia. Appl. Environ. Microbiol. 61-966-971.

3. Ardales, E. Y., Leung, H., Vera Cruz, C. M., Mew, T. W., Leach, J. E., and Nelson, R. J. 1996. Hierarchical analysis of spatial variation of the rice bacterial blight pathogen across diverse agroecosystems in the Philippines. Phytopathology 86:241-252.

4. Devadath, S. 1983. A strain of Oryza barthii, an African wild rice immune to bacterial blight of rice. Curr. Sci. 52:27-28.

5. Excoffier, L., Smouse, P. E., and Quattro, J. M. 1992. Analysis of molecular variance inferred from metric distances among DNA haplotypes: Application to human mitochondrial DNA restriction data. Genetics 131:479491.

6. Felsenstein, J. 1985. Confidence limits on phylogenies: an approach using the bootstrap. Evolution 39:783-791.

7. George, M. L. C., Bustamam, M., Cruz, W. T., Leach, J. E., and Nelson, R. J. 1997. Movement of Xanthomonas oryzae pv. oryzae in southeast Asia detected using PCR-based DNA fingerprinting. Phytopathology 87:302-309.

8. George, M. L. C., Leach, J. E., and Nelson, R. J. 1995. DNA fingerprinting of Xanthomonas oryzae pv. oryzae using IS1112-based polymerase chain reaction. Int. Rice Res. Notes 20(3):30-31.

9. Gupta, A. K., Sharma, S. C., and Saini, R. G. 1986. Variation in pathogenicity of some Indian isolates of Xanthomonas campestris pv. oryzae. Phytopathology 76:881-883.

10. Hedges, S. B. 1992. The number of replications needed for accurate estimation of the bootstrap $P$ value in phylogenetic studies. Mol. Biol. Evol. 9:366-369.

11. Huang, N., Angeles, E. R., Domingo, J., Magpantay, G., Singh, S., Zhang, G., Kumaravadivel, N., Bennett, J., and Khush, G. S. 1997. Pyramiding of bacterial blight resistance genes in rice: marker-assisted selection using RFLP and PCR. Theor. Appl.
Genet. 95:313-320

12. Khush, G. S., Bacalangco, E., and Ogawa, T. 1990. A new gene for resistance to bacterial blight from $O$. longistaminata. Rice Genet. Newsl. 67:121-122.

13. Leach, J. E., Rhoads, M. L., Vera Cruz, C. M. White, F. F., Mew, T. W., and Leung, H. 1992. Assessment of genetic diversity and population structure of Xanthomonas oryzae pv. oryzae with a repetitive DNA element. Appl. Environ. Microbiol. 58:2188-2195.

14. Leung, H., Nelson, R. J., and Leach, J. E. 1993. Population structure of plant pathogenic fungi and bacteria. Adv. Plant Pathol 10:157-205.

15. Nei, M. 1987. Molecular Evolutionary Genetics. Columbia University Press, New York.

16. Nelson, R. J., Baraoidan, M. R., Vera Cruz, C M., Yap, I. V., Leach, J. E., Mew, T. W., and Leung, H. 1994. Relationship between phylogeny and pathotype for the bacterial blight pathogen of rice. Appl. Environ. Microbiol. 60:3275-3283.

17. Ogawa, T., and Khush, G. S. 1989. Major genes for resistance to bacterial blight in rice. Pages 177-192 in: Bacterial Blight of Rice. Proc. Workshop Bacterial Blight Rice. Int Rice Res. Inst. Manila, Philippines.

18. Ogawa, T., Yamamoto, T., Khush, G. S., and Mew, T. W. 1991. Breeding of near-isogenic lines of rice with single genes for resistance to bacterial blight pathogen (Xanthomonas campestris pv. oryzae). Jpn. J. Breed. 41:523-529.

19. Rajebhosale, A. P. K., Chowdari, K. V., Ramakrishna, W., Tamhankar, S. A., Gupta, V. S., Gnanamanickam, S. S., and Ranjekar, P. K. 1997. DNA fingerprinting of Indian isolates of Xanthomonas oryzae pv. oryzae. Theor Appl. Genet. 95:103-111.

20. Rao, Y. P., Mohan, S. K., and Reddy, P. R. 1971. Pathogenic variability in Xanthomonas oryzae. Plant Dis. Rep. 55:593-595.

21. Sneath, P. H. A., and Sokal, R. R. 1973. Numerical Taxonomy. W. H. Freeman and Co., San Francisco.

22. Wang, G. L., Song, W. Y., and Ruan, D. L., Sideris, S., and Ronald, P. C. 1996. The cloned Xa21 confers resistance to multiple Xanthomonas oryzae pv. oryzae isolates in transgenic plants. Mol. Plant-Microbe Interact. 9:850-855.

23. Yap, I. V., and Nelson, R. J. 1996. WinBoot: a program for performing bootstrap analysis of binary data to determine the confidence limits of UPGMA-based dendrograms. IRRI Disc. Ser. No. 14. Int. Rice Res. Inst., Manila, Philippines.

24. Yashitola, J., Krishnaveni, D., Reddy, A. P. K., and Sonti, R. V. 1997. Genetic diversity within the population of Xanthomonas oryzae pv. oryzae in India. Phytopathology 87:760765.

25. Yoshimura, S., Yoshimura, A., Iwata, N., McCouch, S. R, Abenes, M. L., Baraoidan, M. R., Mew, T. W., and Nelson, R. J. 1995. Tagging and combining bacterial blight resistance genes in rice using RAPD and RFLP markers. Mol. Breed. 1:375-387.

26. Zheng K.-L., Zhuang J.-Y., and Wang H.-R. 1998. Performance of resistance gene pyramids to races of rice bacterial blight in Zhejiang Province. Hereditas (Beijing) 20(4):4-6. 